\title{
Kebijakan Tax Amnesty: \\ Suatu Peninjauan dalam Perspektif Etika Deontologi Sebagai Bentuk Pilihan Wajib Pajak dalam Melaksanakan Kewajiban Perpajakan
}

\author{
Indra Lila Kusuma*, Maya Widyana Dewi \\ Sekolah Tinggi Ilmu Ekonomi AAS Surakarta, Indonesia \\ *Email korenpondensi: _ililakusuma@yahoo.com
}

Recieved: 14-10-2018 | Revised: 02-01-2018 | Accepted: 31-01-2018

\begin{abstract}
Abstrak
Tujuan penelitian untuk mengetahui Tax Amnesty Dalam Perspektif Etika Deontologi. Penelitian ini merupakan penelitian kualitatif yang bersifat deskriptif analitik dengan difokuskan pada satu fenomena saja yang dipilih dan ingin dipahami secara mendalam dengan mengabaikan fenomenafenomena lainnya, dalam hal ini yaitu penerapan kebijakan Tax Amnesty. Penelitian ini menggunakan teknik analisis data berupa teknik penyajian data. Yaitu kegiatan ketika sekumpulan informasi disusun, sehingga memberi kemungkinan akan adanya penarikan kesimpulan bentuk penyajian data kualitatif berupa teks naratif. Untuk menjawab rumusan masalah yaitu mengenai tax amnesty dalam perspektif teori etika deontologi, peneliti menggunakan beberapa literatur kepustakaan yang berasal dari berbagai sumber yang berhubungan dengan pembahasan yang ingin diteliti dalam penelitian ini seperti buku-buku, jurnal ilmiah, media elektronik, dan media massa yang ter update. Hasil penelitian ini menunjukkan bahwa penerapan tax amnesty jika ditinjau dari perspektif teori etika deontologi telah berjalan dengan baik dengan diikuti oleh wajib pajak sebagai suatu kewajiban tanpa melihat hasil akhir baik dan buruknya bagi diri wajib pajak tersebut. Hal ini dibuktikan dengan berhasilnya penerapan tax amnesty berupa peningkatan penerimaan pajak dengan total harta yang dilaporkan terdiri dari deklarasi harta dalam negeri Rp 3.676 triliun dan deklarasi harta luar negeri mencapai $R p 1.031$ triliun. Sementara penarikan dana dari luar negeri (reptriasi) mencapai $R p 147$ triliun.
\end{abstract}

Kata Kunci: Tax Amnesty, Etika Deontologi, Wajib Pajak

\begin{abstract}
This research aim to know Tax Amnesty In Perspective Deontology Ethics. This research is a qualitative research that is analytic descriptive with focused on one phenomenon only chosen and want to be understood deeply by ignoring other phenomena, in this case that is implementation of Tax Amnesty policy. This study uses data analysis techniques in the form of data presentation techniques. That is the activity when a set of information is compiled, thus giving the possibility of drawing the conclusion of the form of presentation of qualitative data in the form of narrative text. To answer the formulation of the problem that is about tax amnesty in the perspective of deontology ethical theory, the researcher uses some literature of literature that come from various sources related to the discussion that want to be examined in this research such as books, scientific journals, electronic media, and mass media update. The results of this study indicate that the application of tax amnesty if viewed from the perspective of deontology ethical theory has been running well with followed by the taxpayer as a liability without seeing the final results of good and bad for the taxpayer self. This is evidenced by the successful implementation of tax amnesty in the form of increased tax revenue with total assets reported consisting of domestic property declaration $R p$ 3.676 trillion and declaration of foreign property reached $R p 1.031$ trillion. While the withdrawal of funds from abroad (reptriation) reached $R p 147$ trillion.
\end{abstract}

Keywords: Tax Amnesty, Deontology Ethics, Assessable 


\section{Saran sitasi:}

Kusuma, I., \& Dewi, M. (2018). Kebijakan Tax Amnesty: Suatu Peninjauan dalam Perspektif Etika Deontologi Sebagai Bentuk Pilihan Wajib Pajak dalam Melaksanakan Kewajiban Perpajakan. Jurnal Akuntansi dan Pajak, 18(2), 204-2014. doi: http://dx.doi.org/10.29040/jap.v18i2.118

\section{DOI: http://dx.doi.org/10.29040/jap.v18i2.118}

\section{Pendahuluan}

Pajak merupakan salah satu urat nadi penentu pembangunan suatu bangsa.Karena penerimaan terbesar negara bersumber dari pajak. Pada saat sumber daya alam yang pada umumnya tidak bisa diperbaharui semakin berkurang, maka pajak akan menjadi andalan bagi suatu Negara karena sifatnya yang bertolak belakang dengan sumber daya alam yang relative mempunyai keterbatasan waktu, pajak semakin lama akan semakin bertambah seiring dengan pertambahan pendudukyg menjadi wajib pajak.

Dikarenakan besarnya fungsi pajak bagi penerimaan Negara, maka berbagai cara dilakukan pemerintah untuk bisa memaksimalkan penerimaan pajak. Pemerintah mengelurkan Kebijakan-kebijakan seperti program ekstensifikasi yang fokusnya pada peningkatan jumlah wajib pajak terdaftar, dan intensifikasi yang mengaju pada perluasan objek pajak yang dapat dikenakan pajak (Amali, 2009). Walaupun berbagai kebijakan telah dikeluarkan dan dilaksanakan,namun tetap saya penerimaan pajak belum mencapai angka maksimalyang seharusnya dapat terpenuhi. Menteri keuangan Bambang brojonegoro pada tahun 2015, mengatakan bahwa dari 27.000 wajib pajak orang pribadi yang terdaftar ternyata hanya kurang lebih 10.000 wajib pajak yang taat dalam melakukan kewajibannya sebagai wajib pajak, belum lagi wajib pajak badan yang banyak melakukan kecurangan-kecurangan untuk menghindari pajak seperti kasus terbaru Panama peppers, dan wajib pajak badan yang memang menunggak dalam pembayaran pajak yang terkadang sebagian assetnya harus disita karena ketidak taatan wajib pajakbadan tersebut dalam membayar pajak. (Tempo, 2015).
Dalam menanggulangi berbagai masalah tersebut, maka akhir 2015 pemerintah kembali merencanakan mengeluarkan suatu kebijakan untuk meningkatkan penerimaan pajak.kebijakan tersebut adalah pengampunan pajak (tax amnesty). Tax Amnesty merupakan kebijakan pemerintah di bidang perpajakan yang memberikan penghapusan pajak yang seharusnya terutang dengan membayar tebusan dalam jumlah tertentu yang bertujuan untukmemberikan tambahan penerimaan pajak dan kesempatan bagi wajib pajak yang tidak patuh menjadi wajib pajak patuh.

Tax Amnesty telah berhasil diberlakukan di beberapa Negara seperti India, berupa pengampunan pajak berupa penghapusan sanksi administrasi dari pajak penghasilan. Hasilnya peningkatan penerimaan pajak tiga kali lipat dari jumlah yang diperoleh dalam pemberian pengampunan pajak sebelumnya. Di Irlandia tahun 1988, pengampunan pajak berupa penghapusan sanksi administrasi dalamwaktu 10 bulan dari pajak penghasilan.Hasilnya adalah penerimaan pajak actual (750 juta dolar) 15 kali lipat dari penerimaan pajak yang diestimasi (50 juta dolar). Demikian juga yang terjadi di Colombia dan Colorado, pemberlakuan Tax Amnesty mampu meningkatkan penerimaan pajak secara siknifikan.

Berbeda dengan apa yang terjadi di beberapa negara yang yang telah memberlakukan Tax Amnesty seperti tersebut di atas, di Indonesia rencana pemberlakuan Tax Amnesty oleh pemerintah menuai pro dan kontra dengan berbagai alasan, pemerintah berharap dengan pemberlakuan Tax Amnesty maka akan mampu mengembalikan pajak-pajak yang ada diluar negeri karena banyak pengusaha yang 
menyimpan devisa ekspornya di luar negeri. Para pengusaha melakukan hal tersebut untuk menghindari pajakatau biasa disebut praktek transfer pricing. Sebaliknya yang tidak setuju diberlakukannya Tax Amnesty beralasan bahwa keringanan bagi wajib pajak yang enggan membayar apajak akan menjadi presenden buruk bagi masyarakat yang selama ini taat membayar pajak. Tax Amnesty kontra produktif. Ini membuat orang yang taat membayar pajak menjadi tidaktermotivasi, sebaliknya bagi wajib pajak yang menyembunyikan asset mereka diluar negeri, upaya ini akan mengesankan bahwa pemerintah taktegas ddan bisa ditawar. Jika Tax Amnesty jadi diberikan, maka bukan tidak mungkin pengampunan yang sama akan terulang pada masa yang akan dating (Tempo.com, 2015).

Berdasarkan permasalahan yang ada dalam rencana pemberlakuan Tax Amnesty di Indonesia maka penulis tertarik untuk melihat Tax Amnesty dalam perspektif etika deontology.Etika deontology menegaskan bahwa dalam suatu perbuatan pastti ada konsekwensinya, dalam hal inikonsekwensi perbuatan tidak boleh menjadi pertimbangan, perbuatan menjadi baik bukan dilihat dari hasilnyamelainkan karena perbuatan tersebut wajib dilakukan.Dalam teori etika deontology kewajiban itu tidak bisa ditawar lagi karena itu merupakan suatu keharusan.

\section{Tinjauan Pustaka}

\subsection{Pengampunan Pajak (Tax Amnesty)}

Tax amnesty atau amnesti pajak adalah pengampunan atau pengurangan pajak terhadap properti yang dimiliki oleh perusahaan yang akan segera diatur dalam Undang-Undang pengampunan nasional. Hal-hal yang berkaitan dengan draft UU tersebut dikatakan jika pengampunan pajak adalah penghapusan pajak terutang, penghapusan sanksi administrasi perpajakan, penghapusan sanksi pidana pada bidang perpajakan, maupun sanksi pidana tertentu yang diharuskan membayar dengan uang tebusan. Pengampunan pajak ini objeknya bukan hanya yang disimpan di luar negeri, tetapi juga berasal dari dalam negeri yang laporannya tidak diberikan secara benar.
Dengan adanya tax amnesty atau amnesti pajak ini dapat memberikan manfaat untuk beberapa pihak, baik itu untuk pemerintah, pengembang, maupun untuk investor. Berikut ini manfaat adanya tax amnesty untuk beberapa pihak, yaitu:

a. Untuk Pemerintah

Dengan diberlakukannya tax amnesty atau pengampunan pajak ini maka akan menambah penghasilan penerimaan baru dimana penambahannya dirasa cukup efektif dalam mengurangi penerimaan negara yang semakin berkurang. Dengan diterapkannya tax amnesty atau pengampunan pajak ini maka secara otomatis akan bisa menarik dana yang terdapat di luar negeri ke Indonesia yang menjadikannya masuk ke dalam pencatatan untuk sumber pajak baru. Amnesti pajak yang diasumsikan oleh pemerintah sebanyak Rp. 60 trilyun yang tercantum pada APBN 2016. Nominal tersebut berasal dari tarif tebusan sebesar $3 \%$ dari dana yang masuk yaitu sekitar Rp. 2.000 trilyun.

\section{b. Untuk Pengembang}

Dengan diberlakukannya amnesti pajak maka akan membuat sektor properti mengalami pertumbuhan untuk tahun berikutnya. Kebijakan ini berhubungan dengan pajak yang menjadikan indikator untuk kebangkitan sebuah bisnis properti yang ada di Indonesia. Tax amnesty ini sangat dipercaya untuk memberikan sebuah pengaruh terhdap pengembang untuk dapat terus berhubungan dengan para investor. Para investor selama ini merasa tidak mau untuk menanamkan modalnya di Indonesia karena negara Indonesia mempunyai pajak properti yang tergolong sangat tinggi.

\section{c. Untuk Investor}

Bukan hanya pemerintah dan pengembang saja yang merasa senang dengan kabar ini. Hadirnya tax amnesty atau pengampunan pajak ini juga sangat disambut baik oleh para investor. Dengan adanya tax amnesty atau pengampunan pajak ini akan memberikan keuntungan terhadap kegiatan bisnis. Amnesti pajak ini dapat membuat para konsumen serta investor untuk lebih berani lagi melakukan pembelian terhadap 
properti. Dengan demikian, para investor tidak merasa takut lagi untuk melakukan pembelian properti.

Adapun jenis jenis pengampunan pajak meliputi:

a. Amnesti yang tetap mewajibkan pembayaran pokok pajak, termasuk bunga dan dendanya, dan hanya mengampuni sanksi pidana perpajakan. Tujuannya adalah untuk memungut pajak tahun-tahun sebelumnya, sekaligus menambah jumlah wajib pajak terdaftar.

b. Amnesti yang mewajibkan pembayaran pokok pajak masa lalu yang terutang berikut bunganya, namun mengampuni sanksi denda dan sanksi pidana pajaknya.

c. Amnesti yang tetap mewajibkan pembayaran pokok pajak yang lama, namun mengampuni sanksi bunga, sanksi denda dan sanksi pidana pajaknya.

d. Amnesti yang mengampuni pokok pajak di masa lalu, termasuk sanksi bunga, sanksi denda dan sanksi pidananya. Tujuannya adalah untuk menambah jumlah wajib pajak terdaftar, agar ke depan dan seterusnya mulai membayar pajak (Devano dan Rahayu, 2006).

Silitonga (2006) dalam tulisannya yang berjudul Ekonomi Bawah Tanah dan Pengampunan Pajak berpendapat bahwa salah satu cara inovatif untuk meningkatkan penerimaan pajak tanpa menambah beban pajak baru kepada masyarakat, dunia usaha, dan para pekerja adalah melalui program pengampunan pajak. Pengampunan pajak diharapkan menghasilkan penerimaan pajak yang selama ini belum dibayar dan meningkatkan kepatuhan serta efektifitas pembayaran karena daftar kekayaan wajib pajak makin akurat.

Konsep kemauan membayar pajak (Willingness to Pay Tax) dikembangkan melalui dua sub konsep yaitu, konsep kemauan membayar dan konsep pajak. Pertama konsep kemauan membayar. Kemauan membayar merupakan suatu nilai dimana seseorang rela untuk membayar, mengorbankan atau menukarkan sesuatu untuk memperoleh barang atau jasa (Widaningrum, 2007). Kedua, konsep pajak. Menurut Taylor (Waluyo, 2007) pajak adalah prestasi yang dipaksakan sepihak oleh negara dan terutang kepada pengusaha (menurut norma-norma yang ditetapkan secara umum), tanpa adanya kontraprestasi, dan semata-mata digunakan untuk menutup pengeluaranpengeluaran umum. Sementara menurut Soemitro (1965) pajak adalah iuran kepada kas negara berdasarkan undang-undang (yang dapat dipaksakan) dengan tidak mendapat jasa timbal (kontaprestasi), yang langsung dapat ditujukan dan yang digunakan untuk membiayai pengeluaran umum.

Berdasarkan definisi dari dua sub konsep di atas, maka dapat dikembangkan suatu definisi untuk kemauan membayar pajak (willingness to pay tax). Kemauan membayar pajak dapat diartikan sebagai suatu nilai yang rela dikontribusikan oleh seseorang (yang ditetapkan dengan peraturan) yang digunakan untuk membiayai pengeluaran umum negara dengan tidak mendapat jasa timbal (kontraprestasi) secara langsung.

\subsection{Teori Etika Deontologi}

Etika merupakan ilmu yang mendalami standar moral perorangan dari standar moral masyarakat. Ia mempertanyakan bagaimana standar-standar diaplikasikan dalam kehidupan kita dan apakah standar ini masuk akal atau tidak masuk akal (Velasquez, 2002). Etika yang berasal dari sebuah kata Yunani "ethos" (Rahardjo, 1990) pada hakikatnya memiliki arti filsafat mengenai bidang moral (Suseno, 1997) Bidang moral mengarah pada perilaku manusia, dengan demikian etika dapat dikatakan sebagai suatu penyelidikan atau pengkajian secara sistematis mengenai perilaku (Rahardjo, 1990).

Dewasa ini diskusi etika dalam tataran teoritis kebanyakan lebih merujuk pada dua pengelompokan pemikiran besar, yaitu etika teleologi dan etika deontologi (Ludigdo, 2007) Dua pemikiran ini telah menjadi mainstream dalam mencari pedoman untuk pengembangan praktik etika. Etika teleologi mempunyai 
pandangan mendasar bahwa suatu tindakan dinilai baik atau buruk berdasarkan tujuan atau akibat dilakukannya tindakan tersebut. Sementara Teori Deontologi yaitu berasal dari bahasa Yunani, "Deon" berarti kewajiban. Dalam pemahaman teori deontologi memang terkesan berbeda dengan etika lainnya, Etika deontologi benar-benar melepaskan sama sekali moralitas dari konsekwensi perbuatan. Dalam suatu perbuatan pasti ada konsekwensinya, dalam hal ini konsekwensi perbuatan tidak boleh menjadi pertimbangan. Perbuatan menjadi baik bukan dilihat dari hasilnya melainkan karena perbuatan tersebut wajib dilakukan. Deontologi menekankan perbuatan tidak dihalalkan karena tujuannya. Tujuan yang baik tidak menjadi perbuatan itu juga baik. Disini kita tidak boleh melakukan suatu perbuatan jahat agar sesuatu yang dihasilkan itu baik, karena dalam teori deontologi kewajiban itu tidak bisa ditawar lagi karena ini merupakan suatu keharusan.

\section{Metode Penelitian}

Penelitian ini merupakan penelitian kualitatif yang bersifat deskriptif analitik. Penelitian kualitatif menggunakan desain penelitian studi kasus dalam arti penelitian difokuskan pada satu fenomena saja yang dipilih dan ingin dipahami secara mendalam dengan mengabaikan fenomena-fenomena lainnya, dalam hal ini yaitu penerapan kebijakan Tax Amnesty, sekaligus Tax Amnesty menjadi objek penelitian ini. Variabel penelitian meliputi; Tax Amnesty yaitu pengampunan Pajak yang Diberikan Kepada Wajib Pajak; sementara Etika Deontologi merupakan kesadaran wajib pajak dalam membayar pajak dalam perspektif teori etika deontologi.

Teknik pengumpulan data yang dilakukan dalam penelitian ini adalah melalui observasi tak berstruktur, artinya observasi dilakukan tanpa menggunakan guide observasi. Dengan observasi akan diperoleh pengalaman langsung, sehingga memungkinkan peneliti menggunakan pendekatan induktif. Jadi tidak dipengaruhi pleh konsep atau pandangan sebelumnya. Pendekatan induktif ini membuka kemungkinan penemuan.
Sementara Teknik Analisa Data menurut Miles dan Huberman (2007), terdapat tiga teknik analisis data kualitatif yaitu reduksi data, penyajian data dan penarikan kesimpulan. Penelitian ini menggunakan teknik analisis data berupa teknik penyajian data. Yaitu kegiatan ketika sekumpulan informasi disusun, sehingga memberi kemungkinan akan adanya penarikan kesimpulan bentuk penyajian data kualitatif berupa teks naratif. Untuk menjawab rumusan masalah yaitu mengenai tax amnesty dalam perspektif teori etika deontologi, peneliti menggunakan beberapa literatur kepustakaan yang berasal dari berbagai sumber yang berhubungan dengan pembahasan yang ingin diteliti dalam penelitian ini seperti buku-buku, jurnal ilmiah, media elektronik, dan media massa yang ter update.

\section{Hasil dan Pembahasan}

\subsection{Tax Amnesty}

Tax amnesty atau pengampunan pajak ialah kebijakan pemerintah di dalam bidang perpajakan yang memberikan penghapusan pajak yang semestinya terhutang dengan membayar tebusan dalam jumlah tertentu yang bertujuan memberikan tambahan penerimaan pajak serta kesempatan bagi Wajib Pajak yang tidak patuh menjadi Wajib Pajak yang patuh. Penerapan tax amnesty kemudian diharapkan akan mendorong peningkatan kepatuhan sukarela Wajib Pajak di masa yang akan datang. Sawyer (2006) mengemukakan pendapatnya mengenai arti pengampunan pajak yaitu "a tax amnesty generally involves providing previously noncompliant taxpayers with the opportunity to pay back-taxes on undisclosed income, without fear of penalities or prosecution".

Dari definisi tersebut bisa disimpulkan bahwa tax amnesty atau pengampunan pajak ialah suatu program kebijakan Pemerintah yang memberikan kesempatan kepada para wajib pajak untuk melunasi tunggakan pajaknya tanpa diberikannya sanksi administrasi untuk meningkatkan kepatuhan wajib pajak serta penerimaan negara. 
Tujuan Tax Amnesty diharapkan dapat menghasilkan penerimaan pajak yang selama ini belum ataupun kurang dibayar, disamping meningkatkan kepatuhan membayar pajak. Meningkatnya kepatuhan itu pun merupakan dampak dari semakin efektifnya pengawasan, sebab semakin akuratnya informasi tentang daftar kekayaan Wajib Pajak

Adapun tujuan dari tax amnesty atau pengampunan pajak adalah sebagai berikut:

a. Meningkatkan penerimaan pajak dalam jangka pendek. Permasalahan penerimaan pajak yang stagnan ataupun cenderung menurun seringkali dapat menjadi alasan pembenaran diberikannya tax amnesty. Hal tersebut akan berdampak pada keinginan pemerintah guna memberikan tax amnesty dengan harapan pajak yang dibayar si wajib pajak selama program tax amnesty kemudian akan meningkatkan penerimaan pajak.

b. Meningkatkan kepatuhan pajak di kemudian hari. Kepatuhan pajak ialah salah satu penyebab adanya pemberian tax amnesty. Para pendukung tax amnesty biasanya berpendapat bahwa kepatuhan sukarela akan meningkat setelah program pengampunan pajak dilakukan. Hal tersebut didasari pada harapan bahwa setelah program tax amnesty dilakukan, Wajib Pajak yang sebelum itu menjadi bagian dari sistem administrasi perpajakan, maka Wajib Pajak itu tidak akan bisa mengelak ataupun menghindar dari kewajiban perpajakannya.

c. Mendorong repatriasi modal dan aset. Kejujuran di dalam pelaporan sukarela atas data harta kekayaan setelah program tax amnesty ialah salah satu tujuan pemberian tax amnesty. Dalam konteks ini, data harta kekayaan tersebut, pemberian tax amnesty pun bertujuan guna mengembalikan modal yang parkir di luar negeri tanpa harus membayar pajak atas modal yang di parkir di luar negeri itu. Pemberian tax amnesty atas pengembalian modal dan aset yang di parkir di luar negeri ke bank di dalam negeri dipandang perlu sebab akan memudahkan otoritas pajak di dalam meminta informasi mengenai data kekayaan wajib pajak kepada bank dalam negeri.

d. Transisi ke sistem perpajakan yang baru. Tax amnesty bisa di justifikasi saat tax amnesty digunakan sebagai alat transisi ke sistem perpajakan yang baru.

Sementara Sawyer (2006) mengemukakan beberapa tipe pengampunan pajak (Tax Amnesty), yakni:

a. Filling amnesty. Pengampunan yang diberikan dengan cara menghapuskan sanksi bagi Wajib Pajak yang terdaftar tetapi tidak pernah mengisi SPT (non-filers), pengampunan diberikan bila mereka mau memulai untuk mengisi SPT.

b. Record-keeping amnesty. Memberi penghapusan sanksi untuk kegagalan dalam memelihara dokumen perpajakan pada masa lalu, pengampunan diberikan apabila Wajib Pajak untuk selanjutnya bisa memelihara dokumen perpajakannya.

c. Revision amnesty. Ialah suatu kesempatan untuk memperbaiki SPT pada masa lalu tanpa harus dikenakan sanksi ataupun diberikan pengurangan sanksi. Pengampunan ini memungkinkan para Wajib Pajak untuk memperbaiki SPT-nya yang terdahulu (yang mengakibatkan adanya pajak yang masih mesti dibayar) serta membayar pajak yang tidak (missing) ataupun belum dibayar (outstanding). Wajib Pajak tidak akan secara otomatis kebal terhadap tindakan pemeriksaan serta penyidikan.

d. Investigation amnesty. Pengampunan yang menjanjikan tidak akan adanya penyelidikan sumber penghasilan yang dilaporkan pada tahun-tahun tertentu serta adanya sejumlah uang pengampunan (amnesty fee) yang mesti dibayar. Pengampunan jenis ini pun menjanjikan untuk tidak akan dilakukannya tindakan penyidikan bagi sumber penghasilan ataupun jumlah penghasilan yang sebenarnya. Pengampunan tersebut sering dikenal dengan pengampunan yang berkaitan 
dengan tindakan pencucian (laundering amnesty).

e. Prosecution amnesty. Pengampunan yang memberikan penghapusan tindak pidana terhadap Wajib Pajak yang melakukan pelanggaran undang-undang, sanksi dihapuskan dengan cara membayarkan sejumlah kompensasi.

\subsection{Alasan dan Motivasi Wajib Pajak} Mengikuti Tax Amnesty

Tax Amnesty saat ini menjadi program prioritas dari Kementerian Keuangan (Kemenkeu). Dengan Tax Amnesty, pemerintah meyakini pendapatan negara sektor pajak akan semakin meningkat. Baik pajak dalam negeri maupun pajak dari dana orang Indonesia yang berada di luar negeri. Setelah melawati masa pembahasan yang cukup panjang, Dewan Perwakilan Rakyat (DPR) bersama pemerintah akhirnya mengesahkan Rancangan UndangUndang (RUU) Pengampunan Pajak (Tax Amnesty) menjadi UU.

Berikut 5 alasan utama, mengapa wajib pajak perlu memanfaatkan Tax Amnesty ini :

1) Tax Amnesty kali ini merupakan Tax Amnesty terakhir sebelum era keterbukaan data atau informasi di tahun 2017/2018

Tahun 2017 / 2018 Indonesia akan mulai menerapkan AEOI (Automatic Exchange of Information), dimana tidak ada lagi wajib pajak yang bisa menyembunyikan nilai tabungan, besaran transaksi, dan juga seluruh asset yang dimilikinya, baik itu di dalam negeri maupun di luar negeri. Sehingga pajak dapat melihat dengan transparan mengenai data dari wajib pajak yang akan diperiksa

2) Tax Amnesty menghapuskan semua utang pajak di masa lalu

Dengan mengikuti Tax Amnesty dan disetujui, maka semua utang perpajakan yang kita miliki di masa lalu akan diampuni dan dibebaskan. Namun jika tidak mengikuti Tax Amnesty dan terkena pemeriksaan, tentunya wajib pajak perlu melakukan pemberesan dari seluruh utang pajak yang dimilikinya
3) Tax Amnesty membebaskan semua sanksi administrasi perpajakan di masa lalu

Tidak hanya utang perpajakan, namun semua sanksi administrasi sebesar $2 \%$ per bulan juga akan diampuni. Bayangkan apabila sanksinya dikumulatifkan dari tahun ke tahun berapa besar sanksi yang harus dibayarkan.

4) Tax Amnesty membebaskan semua sanksi pidana perpajakan di masa lalu

Kali ini pemerintah bersama DPR bersungguh-sungguh membuat kebijakan pengampunan pajak. Bahkan hingga sanksi secara pidana perpajakan pun akan diampuni semua, sepanjang berkas penyidikannya belum sampai ke kejaksaan.

5) Dengan mengikuti Tax Amnesty maka akan dihentikan dari pemeriksaan dan penyidikan tindak pidana perpajakan di masa lalu

Untuk yang sedang terkena pemeriksaan dan penyidikan tindak pidana perpajakan pun akan turut serta juga diampuni oleh pemerintah. Dengan demikian Tax Amnesty ini benar-benar bisa dibilang memulai hidup yang baru dari aspek perpajakan.

\subsection{Realisasi Penerimaan Pajak dari penerapan Tax Amnesty}

Program pengampunan pajak tax amnestyyang digulirkan pemerintah sejak Juli 2016, berakhir pada Jumat (31/3/2017) tepat pukul 24.00. Hasilnya, berdasarkan Surat Pernyataan Harta SPH total harta yang dilaporkan para wajib pajak mencapai Rp 4.855 triliun. Berdasarkan data dashboardtax amnesty, total harta yang dilaporkan tersebut terdiri dari deklarasi harta dalam negeri Rp 3.676 triliun dan deklarasi harta luar negeri mencapai Rp 1.031 triliun. Sementara penarikan dana dari luar negeri (reptriasi) mencapai Rp 147 triliun.

Sementara deklarasi hingga 24.00 WIB ada Rp 4.855 triliun, tebusan $\mathrm{Rp} 114$ triliun, ditambah dengan tunggakan dan bukper jadinya Rp 135 triliun," penerimaan negara dari program tax amnesty mencapai Rp 135 triliun. Ini terdiri dari uang tebusan $\mathrm{Rp} 114$ triliun, pembayaran bukti permulaan Rp 1,75 triliun, dan pembayaran 
tunggakan Rp 18,6 triliun.( Direktur Jenderal Pajak Kementerian Keuangan)

\subsection{Etika}

Etika merupakan ilmu yang mendalami standar moral perorangan dari standar moral masyarakat. Ia mempertanyakan bagaimana standar-standar diaplikasikan dalam kehidupan kita dan apakah standar ini masuk akal atau tidak masuk akal (Velasquez, 2002). Seseorang mulai memperdulikan etika ketika dia menggunakan standar moral yang diserap dari keluarga, teman dan bertanya: apakah standar-standar tersebut mengacu pada situasi yang saya hadapi?. Apakah standar tersebut masuk akal?. Apakah alasan untuk mendudung atau menentang standar tersebut. Apakah yang dapat dikatakan untuk mendukungnya dan untuk melawannya?. Apakah cukup masuk akal untuk saya anut? Etika yang berasal dari sebuah kata Yunani "ethos" (Rahardjo, 1990).

Pada hakekatnya memiliki arti "filsafat mengenai bidang moral" (Suseno,1997). Bidang moral mengarah pada perilaku manusia, dengan demikian etika dapat dikatakan sebagai suatu penyelidikan atau pengkajian secara sistematis mengenai perilaku (Rahardjo, 1990).

Dewasa ini diskusi etika dalam tataran teoritis kebanyakan lebih merujuk pada dua pengelompokan pemikiran besar, yaitu etika teleologi dan etika deontologi (Ludigdo, 2007) dua pemikiran ini telah menjadi main stream dalam mencari pedoman untuk pengembangan praktik etika.

\subsection{Teori Pengertian Etika}

Etika berasal dari dari kata Yunani 'Ethos' (jamak - ta etha), berarti adat istiadat. Etika berkaitan dengan kebiasaan hidup yang baik, baik pada diri seseorang maupun pada suatu masyarakat. Etika berkaitan dengan nilai-nilai, tatacara hidup yg baik, aturan hidup yg baik dan segala kebiasaan yg dianut dan diwariskan dari satu orang ke orang yang lain atau dari satu generasi ke generasi yg lain. a. NormaUmum

Norma-norma Umum lebih bersifat umum dan sampai pada tingkat tertentu boleh dikatakan bersifat universal.

1) Norma Sopan santun/ Norma Etiket adalah norma yang mengatur pola perilaku dan sikap lahiriah dalam pergaulan sehari-hari. Etika tidak sama dengan Etiket. Etiket hanya menyangkut perilaku lahiriah yang menyangkut sopan santun atau tata karma.

2) Norma Hukum adalah norma yang dituntut keberlakuannya secara tegas oleh masyarakat karena dianggap perlu dan niscaya demi keselamatan dan kesejahteraan manusia dalam kehidupan bermasyarakat. Norma hukum ini mencerminkan harapan, keinginan dan keyakinan seluruh anggota masyarakat tersebut tentang bagaimana hidup bermasyarakat yang baik dan bagaimana masyarakat tersebut harus diatur secara baik.

3) Norma Moral, yaitu aturan mengenai sikap dan perilaku manusia sebagai manusia. Norma moral ini menyangkut aturan tentang baik buruknya, adil tidaknya tindakan dan perilaku manusia sejauh ia dilihat sebagai manusia.

b. Teori Etika Deontologi.

Deontologi (Deontology) berasal dari kata dalam Bahasa Yunani yaitu : deon yang artinya adalah kewajiban. Dalam suatu perbuatan pasti ada konsekuensinya, dalam hal ini konsekuensi perbuatan tidak boleh menjadi pertimbangan. Perbuatan menjadi baik bukan dilihat dari hasilnya melainkan karena perbuatan tersebut wajib dilakukan. Deontologi menekankan perbuatan tidak dihalalkan karena tujuannya. Tujuan yang baik tidak menjadi perbuatan itu juga baik. Di sini kita tidak boleh melakukan suatu perbuatan jahat agar sesuatu yang dihasilkan itu baik, karena dalam Teori Deontologi kewajiban itu tidak bisa ditawar lagi karena ini merupakan suatu keharusan.

\subsection{Analisis teori etika deontologi dalam pelaksanaan Kebijakan Tax Amnesty}

Etika deontologis adalah teori filsafat moral yang mengajarkan bahwa sebuah tindakan itu 
benar kalau tindakan tersebut selaras dengan prinsip kewajiban yang relevan untuknya. Akar kata Yunani deon berarti 'kewajiban yang mengikat' dan logos berarti "pengetahuan". Istilah "deontology" dipakai pertama kali oleh C.D. Broad dalam bukunya Five Types of Ethical Theory. Etika deontologis juga sering disebut sebagai etika yang tidak menganggap akibat tindakan sebagai faktor yang relevan untuk diperhatikan dalam menilai moralitas suatu tindakan.

Dalam pemahaman teori Deontologi memang terkesan berbeda dengan Utilitarisme. Jika dalam Utilitarisme menggantungkan moralitas perbuatan pada konsekuensi, maka dalam Deontologi benar-benar melepaskan sama sekali moralitas dari konsekuensi perbuatan. "Deontologi" ( Deontology ) berasal dari kata dalam Bahasa Yunani yaitu : deon yang artinya adalah kewajiban. Dalam suatu perbuatan pasti ada konsekuensinya, dalam hal ini konsekuensi perbuatan tidak boleh menjadi pertimbangan. Perbuatan menjadi baik bukan dilihat dari hasilnya melainkan karena perbuatan tersebut wajib dilakukan. Deontologi menekankan perbuatan tidak dihalalkan karena tujuannya. Tujuan yang baik tidak menjadi perbuatan itu juga baik. Di sini kita tidak boleh melakukan suatu perbuatan jahat agar sesuatu yang dihasilkan itu baik, karena dalam Teori Deontologi kewajiban itu tidak bisa ditawar lagi karena ini merupakan suatu keharusan.Contoh : kita tidak boleh mencuri, berbohong kepada orang lain melalui ucapan dan perbuatan.

Para penganut etika deontologis, seperti Immanuel Kant pada tahun 1724-180, sebagai pelopornya misalnya, berpendapat bahwa norma moral itu mengikat secara mutlak dan tidak tergantung dari apakah ketaatan atas norma itu membawa hasil yang menguntungkan atau tidak. Misalnya norma moral "jangan bohong" atau "bertindaklah secara adil" tidak perlu dipertimbangkan terlebih dulu apakah menguntungkan atau tidak, disenangi atau tidak, melainkan selalu dan di mana saja harus ditaati, entah apa pun akibatnya. Hukum moral mengikat mutlak semua manusia sebagai makhluk rasional (Agoes dan Ardana. 2014).

\section{Konsep-konsep Deontologi}

a. Sistem etika ini hanya menenkankan suatu perbuatan di dasarkan pada wajib tidaknya kita melakukan perbuatan itu.

b. Yang disebut baik dalam arti sesungguhnya hanyalah kehendak yang baik, semua hal lain di sebut baik secara terbatas atau dengan syarat. Contohnya : kesehatan, kekayaan, intelegensia, adalah baik juka digunakan dengan baik oleh kehendak manusia. Tetapi jika digunakan oleh kehendak jahat, semua hal itu menajdi jahat sekali.

c. Kehendak menjadi baik, jika bertindak karena kewajiban. Kalau perbuatan dilakukan dengan suatu maksud atau motif lain, perbuatan itu tidak bisa di sebut baik, walaupun perbuatan itu suatu kecendrungan atau watak baik.

d. Perbuatan dilakukan berdasarkan kewajiban, bertindak sesuai dengan kewajiban si sebut legalitas. Dengan legalitas kita memenuhi norma hukum.

Berkaitan dengan kebijakan tax amnesty, maka sudah seharusnya para wajib pajak ikut berperan aktif dan patuh serta antusias untuk mengikuti tax amnesty dikarenakan hal tersebut merupakan kewajiban wajib pajak untuk melunasi pajak pajak terutangnya dimasa lalu agar semua kewajibannya sebagai wajib pajak terselesaikan dengan baik, karena dalam etika deontologi dianggap baik bukan karena tindakan itu mendatangkan akibat baik bagi pelakunya melainkan karena tindakan itu sejalan dengan kewajiban si pelaku. Etika deontologi sama sekali tidak mempersoalkan akibat baik atau buruk dari tindakan tersebut. Akibat dari suatu tindakan tidak pernah diperhitungkan untuk menentukan kualitas moral suatu tindakan. Hal ini akan membuka peluang bagi subjektivitas dari rasionalisasi yang menyebabkan kita mengingkari akan kewajiban kewajiban moral.

Tax amnesty merupakan suatu kebijakan yang menuai pro dan kontra, karena selain bisa membantu untuk memajukan Indonesia 
khususnya dalam meningkatkan pendapatan negara dari pajak, bagi masyarakat kecil kebijakan ini dinilai tidak adil. Menurut mereka yang membayar pajak sesuai dengan ketentuan merasa diperlakukan tidak adil karena kebijakan tax amnesty sejatinya adalah pengampunan pajak bagi orang-orang kaya yang melakukan segala cara untuk menghindari membayar pajak. Pemasukan pajak yang akan didapatkan dari pemberlakuan tax amnesty juga dinilai tidak seimbang dengan besarnya sanksi yang seharusnya diberlakukan kepada mereka yang mengemplang pajak.

Dalam perspektif teori etika deontologi, penerapan tax amnesty sudah dijalankan sebagaimana seharusnya dimana wajib pajak harus menyelesaikan semua kewajiban perpajakannya . Terlaksananya tax amnesty dikarenakan adanya kesadaran dari wajib pajak akan kewajibannya untuk menyelesaikan pajak terutang dengan cara mengungkap harta dan membayar uang tebusan sebagaimana diatur dalam Undang-Undang. Kesadaran yang muncul pada diri wajib pajak juga dipengaruhi oleh banyaknya manfaat yang akan didapat oleh wajib pajak apabila mengikuti tax amnesty, salah satunya yaitu tidak adanya sanksi administrasi perpajakan dan sanksi pidana di bidang perpajakan.

\section{Kesimpulan}

Penerapan tax amnesty jika ditinjau dari perspektif teori etika deontologi telah berjalan dengan baik dengan diikuti oleh wajib pajak sebagai suatu kewajiban tanpa melihat hasil akhir baik dan buruknya bagi diri wajib pajak tersebut. Hal ini dibuktikan dengan berhasilnya penerapan tax amnesty berupa peningkatan penerimaan pajak dengan total harta yang dilaporkan terdiri dari deklarasi harta dalam negeri Rp 3.676 triliun dan deklarasi harta luar negeri mencapai $\mathrm{Rp}$ 1.031 triliun. Sementara penarikan dana dari luar negeri (reptriasi) mencapai Rp 147 triliun.

Melihat program tax amnesty yang sudah berjalan ini maka sebaiknya program ini perlu adanya suatu program pendukung untuk keberhasilan secara menyeluruh, misalnya dengan Tax Amnesty Campaign yang dilakukan di semua lapisan masyarakat baik itu dengan jalur pendidikan maupun non pendidikan. Pasca berakhirnya tax amnestysebaiknyadilakukan penegakan hukum pajak yang tegas bagi wajib pajak yang tidak patuh yang tidak ikut tax amnesty. Sehubungan dengan teori etika deontologi, maka sebaiknya program Tax Amnesty ini bisa merangkul semua wajib pajak untuk melakukan kewajibannya dalam pembayaran pajak, sehingga keberhasilan program ini dapat dicapai seoptimal mungkin. Karena perlu kita ingat jika penerimaan pajak meningkat maka kesejahteraan masyakatpun akan mengalami peningkatan. Cara perangkulan wajib pajak bisa dilakukan dengan melakukan pendekatan-pendekatan transformasional kepada masyarakat supaya nantinya semua wajib pajak mengikuti program tax amnesty menjadi suatu kewajiban tanpa melihat hasil akhir yang baik dan buruknya bagi diri wajib pajak.

\section{Ucapan Terimakasih}

Penulis ingin mengucapkan terimakasih kepada Sekolah Tinggi Ilmu Ekonomi AAS Surakarta yang telah mendukung selesainya penelitian ini.

\section{Daftar Pustaka}

Agoes, Sukrisno I dan Cenik Ardana. (2014). Etika Bisnis dan Profesi. Jakarta, Salemba Empat

Amali, Muhhamad Na'im. (2009). Skema Penghindaran Pajak Dalam Perspektif Foreign Direct Investment (FDI), http://catatannaim.blogspot.com/2014/11/s kema-penghindaran-pajak-dalam.html

Devano, Sony dan Siti Kurnia Rahayu. (2006). Perpajakan: Konsep, Teori, dan Isu. Jakarta: Kencana

Ludigdo, Unti. (2007). Paradoks Etika Akuntan, Yogyakarta : Pustaka Pelajar

Miles, Mattew B dan A. Michael Huberman. (2007). Analisis Data Kualitatif, Bukit sumber tentang metode- metode barn. Jakarta: Universitas Indonesia Press. 
Rahardjo, M. Dawam. (1990). Etika Ekonomi dan Manajemen. Yogjakarta : PT. Tiara Wacana Jogja.

Sawyer, Adrian. (2006). Targeting Amnesties at Higrained Evasion a New Zealand Initiative Warrantiy Wider Consideration. Journal, Taxation and Business Law, Department of Accountancy, Finance and Information Systems - University of Canterbury, http://www.austili.edu.au/

Silitonga, Erwin. (2006). Makalah berjudul: Ekonomi Bawah Tanah, Pengampunan Pajak dan Referendum.

Soemitro, Rochmat. (1965). Peradilan Administrasi dalam Hukum Pajak di Indonesia. Bandung: PT. Eresco

Suseno, Franz Magnis, Jaya Suprana, dkk., (1997). Membangun kualitas bangsa Jakarta : Kanisius

Suseno, Franz Magniz. (1997). Etika Jawa. Jakarta : PT. Gramedia.
Tempo, (2015). Tax Amnesty Dinilai Bikin Wajib Pajak Tak Termotivasi. https://bisnis.tempo.co/read/710638/taxamnesty-dinilai-bikin-wajib-pajak-taktermotivasi

Velasquez, Manuel G. (2002). Business Ethics: Consepts and Cases Fift Edition. New Jersey, Mc. Pearson Education.

Waluyo. (2007). Perpajakan Indonesia. Jakarta: Salemba Empat.

Widaningrum, Dwi. (2007). Identifikasi Kemampuan dan Kemauan Membayar Masyarakat Berpenghasilan Menengah Rendah.

http://www.sappk.itb.ac.id/ppk/images/stor ies/pdf/ringkasan_dwi.pdf 